\title{
The effect of increase in the temperature on the foraging of Acromyrmex lobicornis (Hymenoptera: Formicidae)
}

\author{
Rodrigo Tizón ${ }^{1 *}$, Juan Pedro Wulff ${ }^{2}$ and Daniel Valerio Peláez ${ }^{3}$
}

\begin{abstract}
Background: The leaf-cutting ants appear to be a suitable group for studying the effect of global warming on ectothermic animals. These ants of the Atta and Acromyrmex genera are considered to be the main herbivores in the Neotropics. They have patterns of harvesting associated with ranges of temperature. Acromyrmex lobicornis has the widest geographical distribution in Argentina. Peak activity has always been recorded in spring and at the beginning of autumn, being slightly lower in summer when they forage at night, and activity ceases almost completely in winter. In order to evaluate how an increase in temperature affects the activity of A. lobicornis, we studied the amount of foraging and the trophic preferences in two treatments under controlled humidity and temperature conditions $\left(\Delta 4.5^{\circ} \mathrm{C}\right)$ and we also measured the walking speed of the workers as a function of an increase in temperature $\left(6^{\circ} \mathrm{C}\right.$ to $\left.32^{\circ} \mathrm{C}\right)$.

Results: The rate of harvesting was 33\% higher in the warmer treatment. There was a tendency for the ten forage items evaluated to be harvested at the higher temperature. The trophic preference, with or without heat, showed some variation for different items: the shoots of Olea europaea and the dry Schinus molle were the most harvested with heat and without heat, respectively.

Conclusions: Our results support the hypothesis that the ants' activity changes at higher temperature, with higher rates of harvesting and a change in walking speed is observed. There is also variation in the trophic preference, selecting plant items with a higher composition of elements that are degradable by symbiotic fungi. The average walking speed of the workers increased gradually as a function of an increase of temperature up to a maximum speed of $2.85 \mathrm{~cm} / \mathrm{s}$. Our results suggest that small variations in ambient temperature significantly affect certain behavior patterns in the leaf-cutting ants.
\end{abstract}

Keywords: Acromyrmex lobicornis; Global warming; Locomotor activity; Foraging preferences

\section{Background}

The climate change concept refers to a modification in the state of the climate that is identifiable by an alteration in the mean and/or in the variability of its properties that persists for a prolonged period of time, measured in hundreds of years (IPCC 2007). Global warming is unequivo$\mathrm{cal}$, and a sequence of events over the last 100 years makes this evident: increase in mean global temperature of Earth's surface $\left(+0.74^{\circ} \mathrm{C}\right)$, retreat of glaciers and permanent snow in high mountains, rise in the sea level, and

\footnotetext{
* Correspondence: frtizon@criba.edu.ar

'CERZOS-CONICET, CCT-Bahía Blanca, San Andrés 850, Bahía Blanca 8000, Argentina

Full list of author information is available at the end of the article
}

increased frequency of events such as floods and droughts on a global scale (IPCC 2007). Weather maps were made for Argentina according to the projections generated by the climate model developed by CIMA/CONICET (Nuñez et al. 2005). Using this model, the present climate, represented by the 1981 to 1990 decade, was compared with the 2081 to 2090 decade to show the trend in climate change in southern South America over the next 100 years (Nuñez 2009). The following greenhouse gas emission scenarios were highlighted: A2 and B2 (increasing emission of $\mathrm{CO}_{2}$ intermediate between emission scenarios), A1F1 (more extreme), and B1 (with the least change) (IPCC 2001, 2007). The emission scenarios A2 and B2 were selected to make the model, as they are intermediate 
between the scenarios proposed by IPCC (2001, 2007). Under scenario A2, the temperature shows a positive tendency for all geographic areas (although there is also seasonal variation); a marked N-S (north-south) gradient is seen with an increase in mean annual temperature of between $4^{\circ} \mathrm{C}$ and $4.5^{\circ} \mathrm{C}$ for the $\mathrm{N}$ of Argentina and between $2.5^{\circ} \mathrm{C}$ to $3^{\circ} \mathrm{C}$ and $2^{\circ} \mathrm{C}$ to $2.5^{\circ} \mathrm{C}$ for the center and $\mathrm{S}$ respectively, whereas for the Andes, there is a N-S gradient between $4.5^{\circ}$ and $2^{\circ} \mathrm{C}$. The extreme value was detected in scenario A2 in the spring with an increase of $6^{\circ} \mathrm{C}$ in the mean seasonal temperature in the $\mathrm{N}$ of Argentina. In scenario $\mathrm{B} 2$, the spatial distribution of warming is similar to scenario $\mathrm{A} 2$ but with values between $2.5^{\circ} \mathrm{C}$ to $3^{\circ} \mathrm{C}, 1.5^{\circ} \mathrm{C}$ to $2^{\circ} \mathrm{C}$, and of $1^{\circ} \mathrm{C}$ for the $\mathrm{N}$, center, and $\mathrm{S}$ of the country, respectively (Nuñez et al. 2005; Nuñez 2009).

Many studies have analyzed the biotic or abiotic factors that define the geographic gradients of the richness, diversity, and abundance of species, and in all cases, $a$ priori, a positive correlation with the temperature is seen (e.g., Kaspari 2004; Kaspari et al. 2000a, b, 2004; Sanders et al. 2007; Buckley and Jetz 2008; Storch 2010). The survival and reproduction of an organism are related to its capacity to become adapted to the limitations imposed by the environment, sometimes thermic, that directly affect the level of biochemical reactions, and interact with the physiology and behavior of the organism (Angilletta et al. 2002; Hochochka and Somero 2002). The magnitude of which an environmental factor acts as a limit for the survival and reproduction of an organism is a function that varies according to the sensibility of the individual to the environmental factor, and in particular, the ectotherms are more closely related to variations in ambient temperature than organisms capable of regulating their body temperature through metabolism (Huey and Stevenson 1979; Angilletta et al. 2002; Cooper et al. 2008). Thermoregulation is not exclusive to endotherms (May 1979); however, in general, for ectotherms there is an optimum temperature range and a narrow range of tolerance in which they are capable of carrying out their physiological functions, such as locomotion, growth, and reproduction (Huey and Stevenson 1979; Angilletta et al. 2002; Cooper et al. 2008; Deutsch et al. 2008). Insects comprise the majority of terrestrial biodiversity (Bale et al. 2002), and as ectotherms they are vulnerable to variation in temperature (Angilletta et al. 2002; Deutsch et al. 2008). A common approach, seen in work on insects of the effects of temperature on their behavioral habits and physiological processes, is the study of functions such as locomotion (flight) and reproduction or growth rate (May 1979; Bale et al. 2002). Habits that are linked to variation in temperature are the way they search for food and other forms of locomotion, e.g., walking over the ground (Vogt et al. 2003; Angilletta et al. 2008; Jumbam et al. 2008).
Ants are the group most often used to study these interactions as they lack anatomical structures for flight, with the exception of the initial sexual state. Moreover, it is a taxon that shows variable feeding habits and different types of behavior, such as hunting, collecting (seeds and other dead animals), harvesting leaves, and cultivation of symbiotic fungi (Hölldobler and Wilson 1990).

In general, ants forage (search and collect) when the ambient temperature is between $10^{\circ} \mathrm{C}$ and $40^{\circ} \mathrm{C}$ (Hölldobler and Wilson 1990). Temperatures outside this range may be stressful, as they are close to the limits of thermic tolerance and survival (Bestelmeyer 2000; Hartley and Lester 2003; Angilletta et al. 2007; Jumbam et al. 2008; Bollazzi et al. 2008; Bollazzi and Roces 2011). However, some species live in deserts, e.g., Pogonomyrmex spp. that forage with soil temperatures higher than $50^{\circ} \mathrm{C}$ (Pol and Lopez de Casenave 2004; Bucy and Breed 2006; Cole et al. 2010). The soil temperature is directly related to the ambient temperature, especially in semiarid regions with a large percentage of bare ground (Hölldobler and Wilson 1990; Vogt et al. 2003). The extreme temperatures are considered to be the most significant stress factor for ants in arid and semiarid regions. Temperature directly affects foraging activities due to its effects on oxygen consumption, water loss, and transport cost. However, several species of ants have become adapted to high temperatures and they show various strategies for enduring or avoiding these situations (Pol and Lopez de Casenave 2004; Cole et al. 2010). Temperature is a key factor for different groups of ants that compete for resources at the same site, to such an extent that they become competitive, and there is a positive correlation between the dominant species in a community and the optimum temperature for foraging (Cerdá et al. 1998; Angilletta et al. 2007; Lessard et al. 2009).

The leaf-cutting ants appear to be a suitable group to test the hypothesis associated with global warming. This group is defined on the basis of its feeding habits and consists of Atta and Acromyrmex genera, the dominant herbivores of the Neotropics that can harvest up to $17 \%$ of the primary productivity (Hölldobler and Wilson 1990). They have harvesting patterns associated with ranges of the following: specific temperatures for each species and their activity ceases outside those ranges (Hölldobler and Wilson 1990; Pilati and Quirán 1996; Bollazzi 2008; Bollazzi and Roces 2011); temperatures for the close regulation of cultivating symbiotic fungi - the protein source of the colony (Bollazzi and Roces 2010; Mueller et al. 2011); and territorial behavior (Hölldobler and Lumsden 1980) and aggressive behavior between colonies, associated with the dear enemy phenomenon (Fisher 1954; Dimarco et al. 2010). In the Attini tribe, Acromyrmex lobicornis Emery has the widest geographical distribution in Argentina, being found from the north down to the $44^{\circ} \mathrm{S}$ 
parallel in the province of Chubut (Kusnezov 1978; Farji-Brener and Ruggiero 1994). Although its ample geographical distribution suggests that it harvests a wide variety of plant species, there are few studies on its diet in the different habitats where it is found (Farji Brener and Protomastro 1992; Pilati et al. 1997; Franzel and Farji-Brener 2000). A. lobicornis behaves as a generalist species: it forages both monocotyledons and dicotyledons; it uses a wide range of species for cultivating the symbiotic fungus; it is an opportunist, taking advantage of food resources when they are available (spatially and seasonally). It also exploits habitats of low complexity and intense aridity, which has given it adaptive plasticity favoring its wide geographical distribution (Pilati et al. 1997; Claver 2000). Variations may be observed in the harvesting patterns of the species linked to temperature, depending on the geographic locality, although they are close to those generally cited for ants, at $10^{\circ} \mathrm{C}$ to $40^{\circ} \mathrm{C}$ (Hölldobler and Wilson 1990). Harvesting patterns in relation to soil temperature were recorded in two studies and the temperature ranges observed were $10^{\circ} \mathrm{C}$ to $40^{\circ} \mathrm{C}$ (Claver 2000) and $17^{\circ} \mathrm{C}$ to $28^{\circ} \mathrm{C}$ (Nobua Behrmann et al. 2010), in both cases in the desert in the center of the Monte in the province of Mendoza, Argentina. On the other hand, in a study undertaken in the province of La Pampa, harvesting activity of A. lobicornis was seen over an ambient temperature range of $11.7^{\circ} \mathrm{C}$ to $22.6^{\circ} \mathrm{C}$ (Pilati and Quirán 1996). In all cases, peaks of activity were recorded during spring and at the beginning of autumn, whereas activity ceases almost completely during the winter. Moreover, in summer their foraging behavior changed from diurnal to nocturnal harvesting, always within the determined temperature limits and the same as those recorded for daytime (Pilati and Quirán 1996; Claver 2000; Nobua Behrmann et al. 2010). Likewise, in a study on Acromyrmex heyeri (Bollazzi 2008), in anthills and underground, it can be seen how the soil and air temperature vary during the winter, autumn, and summer. There is hardly any difference between the maximum soil and air temperatures during the three seasons, but the minimum temperature of the air is $5^{\circ} \mathrm{C}$ to $7^{\circ} \mathrm{C}$ lower than that of soil over the whole period.

This study aims to increase the knowledge of two aspects of the biology of $A$. lobicornis in a controlled environment and of their interactions with the temperature. Each aspect of the effect of variation in temperature was analyzed separately: (a) to evaluate the harvesting activity, by offering different items normally harvested by the species in the area, under two treatments, with a difference in mean temperature of approximately $4.5^{\circ} \mathrm{C}$ (scenario A2); (b) to measure the magnitude of the modification in the locomotor activity (walking speed) of the workers, in function of a gradual increase in temperature $\left(6^{\circ} \mathrm{C}\right.$ to $\left.32^{\circ} \mathrm{C}\right)$.

\section{Methods}

\section{Study area}

The field work was conducted on land belonging to the Departamento de Agronomía, with coordinates of $38^{\circ} 41^{\prime} \mathrm{S}$; $62^{\circ} 15^{\prime} \mathrm{W}$ (Figure 1). Laboratory activities were carried out in the facilities of the Ant Study Group - CERZOSCONICET, Universidad Nacional del Sur (UNS), Altos del Palihue 8000, Bahía Blanca.

Sampling and observations were conducted prior to the study in order to characterize the study area and to complement the theoretical information already collected.

\section{Climate}

Historical climatic data from Bahía Blanca, recorded in the meteorological station: 877500 (SAZB), at the city airport $\left(38.73^{\circ} \mathrm{S} ; 62.16^{\prime} \mathrm{W}\right)$, at an altitude of $75 \mathrm{~m}$ (Aeródromo de Bahía Blanca 2011).The means for the last 40 years (1970 to 2010): mean annual temperature, $15.4^{\circ} \mathrm{C}$; maximum mean annual temperature, $22.8^{\circ} \mathrm{C}$; minimum mean annual temperature, $9.0^{\circ} \mathrm{C}$; annual precipitation - rain and melted snow, $711.1 \mathrm{~mm}$; mean annual wind speed, $23.3 \mathrm{~km} / \mathrm{h}$; and climatic data of 2011 are shown in Table 1.

\section{Soil}

The study site is in the lower valley of the Naposta stream, which is located at the distal end of the western plain surrounding the Ventania range. The valley was shaped during a humid paleoclimate whereby the slopes are very extensive in comparison to the current stream bed. The slope of the sector is $4 \%$ to $5 \%$, simple, and running $150 \mathrm{~m}$ in a SW-NE direction. A description of a soil profile at $38^{\circ} 41^{\prime} \mathrm{S} ; 62^{\circ} 15^{\prime} \mathrm{W}$ shows that materials are derived from wind-eroded sediments of moderately coarse texture. The morphology of the profile shows a succession of horizons (A)-C-Ck1-2Ckm (layer of coarse calcareous soil 'tosca' or petrocalcic horizon) and it is classified as a moderately deep coarse loamy, thermic, petrocalcic Paleustol. Its main limitations are related to its low chemical fertility ( $1 \%$ total OM), coarse texture (sandyloam), poor structure, low water holding capacity $(70 \mathrm{~mm}$ in a depth of $1 \mathrm{~m}$ ), a limited effective depth (tosca is found between 0.30 and $1 \mathrm{~m}$ ), and high susceptibility to water and wind erosion (Bravo, personal communication).

\section{Experimental design \\ Foraging activity}

The leaf-cutting ant A. lobicornis behaves as a generalist species, as it uses both monocotyledons and dicotyledons: as polyphagous, for the wide range of species used to grow the fungus, and as an opportunist, for its use of the available food sources and for adapting its patterns of activity to the seasonal conditions (Pilati and Quirán 1996; Pilati et al. 1997; Claver 2000; Franzel and Farji-Brener 2000). 


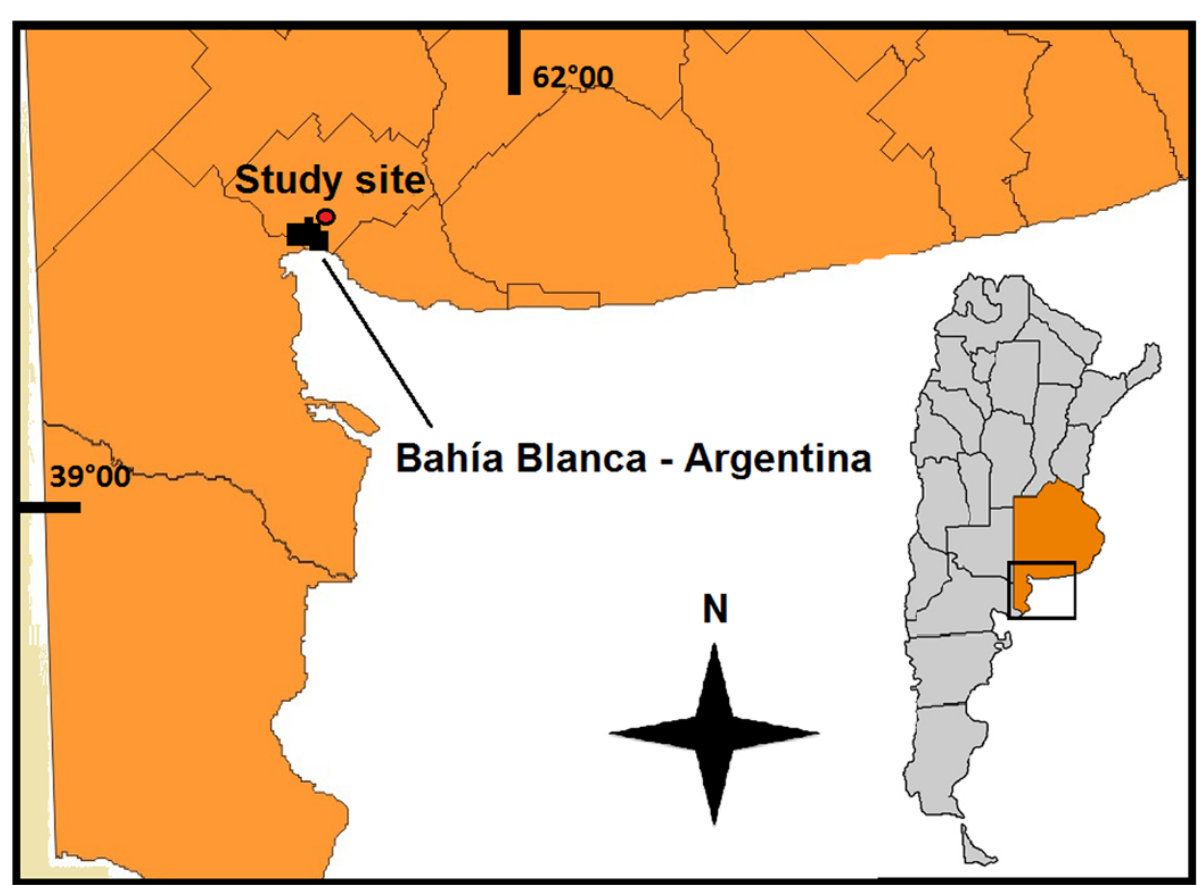

Figure 1 Study area where ant nests were collected. Bahía Blanca, Argentina ( $38^{\circ} 41^{\prime}$ S; $62^{\circ} 15^{\prime} \mathrm{W}$ ).

\section{Construction of artificial nests}

Glass tanks, 30-cm wide and 40-cm deep, were used for the nests. The top of the tank was closed with wood fiber board of the same dimensions as the tank, in which a rectangular door $(15 \mathrm{~cm} \times 25 \mathrm{~cm})$ was cut. The door was closed using a stainless steel mesh $(100 \mu \mathrm{m})$ sealed with a strip of $1 \mathrm{~cm}$ Velcro (stuck with contact cement to the perimeter of the mesh and on the perimeter of the opening in the chapadur) so that the mesh could be removed. Two plastic containers with lids were placed in each nest, one to serve as a feeder $(14.3 \mathrm{~cm} \times 14.3 \mathrm{~cm})$ and the other for garbage $(12.4 \mathrm{~cm} \times 8.6 \mathrm{~cm})$. In both cases, a tube $(15-\mathrm{cm}$ long and $3 / 4$ in diameter, graduated every $1 \mathrm{~cm}$ ) was placed as an entrance to the containers in order to measure the speed of the ants when foraging. Infrared 100-W lamps, regulated with a timer, were used to reach the required temperature, in successive sequences of $2 \mathrm{~h}$ on $/ 2 \mathrm{~h}$ off.

\section{Nest collection}

In total, 22 nests were found at the study site of which 6 were empty. About 400 individuals were collected at random from 16 nests without making any caste distinction, so the percentage of workers collected was at random. No queens, larvae, eggs, or symbiotic fungi were found (with the exception of three nests where fungus was found) and therefore these elements were not included in the samples. A sample of earth and nesting material (approximately $2 \mathrm{~kg}$ ) was taken from each nest so that the workers could build new (artificial) nests. About $2 \mathrm{~g}$ of symbiotic fungus from a larger nest near to the study area was added to each nest. The sample of fungus was previously wetted with distilled water to decrease the pheromones associated with the original colony to some extent, thereby avoiding any possible rejection of the fungus (Lambardi et al. 2007; Richard et al. 2007; Poulsen and Boomsma 2005). Twenty days later, we replenished the populations of the nests with between 100 and 400 workers, depending on the mortality rate in each nest. At the same time, we added a second sample of symbiotic fungus, $2 \mathrm{~g}$ for each nest, to make sure that there was some fungus present. The observations were started a week later.

Table 1 Seasonal means for 2011

\begin{tabular}{|c|c|c|c|c|c|c|c|}
\hline Season & $\mathrm{T}$ med & $\mathrm{T} \max$ & $\mathrm{T} \min$ & Ppm & Ws (med) & Ws (max) & D. Dom \\
\hline Autumn & 14.18 & 28.20 & 1.58 & 30.90 & 7.03 & 55.13 & NNW \\
\hline Winter & 10.00 & 22.50 & -3.80 & 6.70 & 6.40 & 55.50 & NNW \\
\hline Spring & 14.05 & 27.80 & -2.75 & 18.80 & 7.15 & 58.75 & NNW \\
\hline
\end{tabular}

Values of mean, maximum, and minimum temperature ( $\mathrm{T}$ med, $\mathrm{T}$ max, and $\mathrm{T}$ min) were measured in degrees Celsius, precipitation in millimeter, and wind speed (Ws) in kilometer per hour. D. Dom is the direction of the prevailing wind. 


\section{Forages}

The selected items for the experiment were the same plant species used by $A$. lobicornis where it normally feeds in its natural habitat (Table 2).

\section{Treatments}

Two treatments were used to study the interactions between a given range of temperatures and the foraging activity of $A$. lobicornis:

Tamb: ambient temperature

Tamb+: ambient temperature $+4.5^{\circ} \mathrm{C}$

Both treatments were subjected to natural variations in temperature (daily and seasonal), which define the temperature ranges in each treatment (range $=$ mean temperature of the treatment $[ \pm] n$ degrees). The experiment was performed during spring 2011 in an observation chamber, which is an 'open' room with temperature fluctuations similar to the exterior temperature. The difference of $4.5^{\circ} \mathrm{C}$ between treatments is measured as the amplitude between the mean temperatures in each treatment. The range of temperatures for each treatment was recorded once a minute throughout the experiment. A Campbell 21X datalogger (Campbell Scientific Inc., North Logan, UT, USA) connected to a PC was used to record the temperatures.

Each treatment was applied to eight experimental units (e.u.) selected at random. Ten forage items were offered and a photoperiod of 12/12 h was used (Valderrama et al. 2006).

The rate of foraging under each treatment was measured and also for each forage item individually, by counting the units of each item harvested from the feeder. Twenty portions of each item were provided. Every 3 days, the forage items were replaced with fresh material and the number of units of each forage type harvested was counted. In total, ten measurements were taken (repetitions). After each repetition, the nests were

Table 2 Details of ten forage items as presented to the ants and their state of maturity

\begin{tabular}{lll}
\hline Species & Piece & State \\
\hline Cynodon dactylon & Leaf & Mature \\
Diplotaxis tenuifolia & Leaf & Mature \\
Olea europaea & Leaf & Mature \\
Olea europaea & Leaf & Shoot \\
Piptochaetium napostaense & Leaf & Mature \\
Prunus cerasifera & Petal & Mature \\
Rhynchosia diversifolia & Stem with leaves & Mature \\
Schinus molle & Leaf & Mature \\
Schinus molle & Leaf & Dry \\
Solanum sisymbrifolium & Leaf & Dry \\
\hline
\end{tabular}

wetted using a spray bottle, with approximately $75 \mathrm{ml}$ water per nest, which gave a relative humidity of between $60 \%$ and $65 \%$ (90\% after wetting) for nests in the Tamb treatment and $40 \%$ to $50 \%$ (85\% after wetting) for Tamb + .

The graduated tubes at the entrance of each feeder, previously described, were used to measure the walking speed in the harvesting trial. Measurements were made of the walking speed of unladen workers in centimeter per second without making any distinction of subcaste. The walking speed of five workers per nest was measured (these values were then averaged to give a walking speed per nest for each repetition $(n=10))$, and the procedure was repeated at the same time as the replenishment of material and measurement of harvest per forage item.

\section{Temperature of the treatments}

The range of temperatures in the observation room for the Tamb treatment was between $19.5^{\circ} \mathrm{C}$ and $22.9^{\circ} \mathrm{C}$, with a mean temperature for the whole period of $21.7^{\circ} \mathrm{C}$; for the Tamb + treatment, it was between $22.2^{\circ} \mathrm{C}$ and $30.1^{\circ} \mathrm{C}$, with a mean temperature for the whole trial of $26.4^{\circ} \mathrm{C}$. The variation in the mean temperature for each treatment during the trial and also the maximum and minimum temperatures reached in each treatment were recorded.

Both treatments were affected by seasonal variation in temperature, however, the mean temperature of the heat treatment was always higher than the mean for the treatment at ambient temperature, with an average temperature range of $4.5^{\circ} \mathrm{C}\left( \pm 0.75^{\circ} \mathrm{C}\right)$.

\section{Locomotor activity}

In order to establish the effect of temperature on walking speed, the speed was measured at ambient temperatures between $6^{\circ} \mathrm{C}$ and $32^{\circ} \mathrm{C}$, which are below and above the activity range of $11.7^{\circ} \mathrm{C}$ to $28^{\circ} \mathrm{C}$ cited for A. lobicornis $\left(11.7^{\circ} \mathrm{C}\right.$ to $22.6^{\circ} \mathrm{C}$ Pilati et al. 1997 and $17^{\circ} \mathrm{C}$ to $28^{\circ} \mathrm{C}$ Nobua Behrmann et al. 2010). A brood chamber was used to reach the desired temperature in each case.

Individuals were collected from a colony at the study site. The nest was built from a 20-1 plastic container, closed on top by a perforated lid to allow ventilation, and two 1-1 containers were added (as feeder and garbage), connected to the main container by graduated (every $1 \mathrm{~cm}$ ) tubes $15-\mathrm{cm}$ long, with $3 / 4$ in diameter. The new colony included a queen and symbiotic fungus from the original colony. A $12 / 12 \mathrm{~h}$ photoperiod was used (Valderrama et al. 2006), and the colony was fed on fresh petals of Pelargonium hortorum (collected the same day) during the trial.

The walking speed of unladen workers $(\mathrm{cm} / \mathrm{s})$ was measured at a range of temperatures between $6^{\circ} \mathrm{C}$ and $32^{\circ} \mathrm{C}$, at $2^{\circ} \mathrm{C}$ intervals, taking 30 measurements per 
temperature. This was carried out by day with an aclimatization period of $24 \mathrm{~h}$ between one measurement and the next.

\section{Statistical analysis}

Data for the quantity and speed of foraging and forage preference were analyzed with non-parametric models, after carrying out normality homoscedasticity tests Shapiro-Wilks and de Levene, respectively - required for parametric models (Balzarini et al. 2008). Tests of Wilcoxon with two tails were performed to compare the results obtained of quantity (20 portions) and harvesting speed $(\mathrm{cm} / \mathrm{s})$ in function of the different temperatures $\left(21.7^{\circ} \mathrm{C}\right.$ and $\left.26.4^{\circ} \mathrm{C}\right)$. In order to compare forage preference (ten items), a non-parametric analysis of variance to one-way classification proposed by Kruskal-Wallis and comparisons of pairs between the means of the ranges of treatments $(\alpha=0.05)$ were performed. This test allows the comparison of more than two distributions or more expected distributions without the necessity of complying with the assumption of normal distribution for the terms of error (Balzarini et al. 2008).

Analysis of the ants' walking speed $(\mathrm{cm} / \mathrm{s})$, in function of a gradual increase in the ambient temperature $\left(6^{\circ} \mathrm{C}\right.$ to $32^{\circ} \mathrm{C}$ ), was performed using simple polynomial regressions (grades 2, 3, and 4). A logarithmic transformation to base 10 was previously applied to the data to comply with the supposed requirements of the model. The results are presented without transformation to facilitate their interpretation.

\section{Results}

\section{Foraging activity}

The rate of harvesting was $33 \%$ higher under the treatment of ambient temperature $+4.5^{\circ} \mathrm{C}(\mathrm{Tamb}+)(W=95$, $p=0.03)$ when all foraged items were considered together. The patterns of harvesting by $A$. lobicornis showed variable levels of preference between the different items, both in the ambient temperature treatment (Tamb) $(H=54.7$, $p=0.0001)$ and in the Tamb + treatment $(H=52.5, p=0.0001)$. In both treatments, Piptochaetium napostaense (leaf) was the least harvested item, and Prunus cerasifera (petal) the most harvested (Figures 2 and 3).

All ten forage items used in the study were harvested in greater proportion under heat treatment (Figure 4A,B,C, D,E,F,G,H,I,J), and significant differences between treatments were found in four of them: Diplotaxis tenuifolia ( $W=95, p=0.0026$ ) (Figure 4B); Olea europaea shoot ( $W=99, p=0.0003$ ) (Figure 4D); Rhynchosia senna ( $W=90$, $p=0.0207$ ) (Figure 4G); Schinus molle mature $(W=87$, $p=0.0457$ ) (Figure $4 \mathrm{H}$ ). On the other hand, there were no differences between treatments for two of the forage items: Piptochaetium napostaense ( $W=69, p=0.9394)$ (Figure 4E); P. cerasifera ( $W=68.5, p>0.9999)$ (Figure 4F).
Two items were offered in two different states: $O$. europaea (mature and shoot) and S. molle (mature and dry). The shoots of $O$. europaea were harvested in greater proportion than the dry material in both treatments (Figures 2 and 3 ), although the difference was only statistically significant $(H=52.5, p=0.0001)$ under the Tamb + treatment (Figure 3). However, the dry material of S. molle was harvested in greater proportion than the mature in both treatments (Figures 2 and 3), although it was only statistically significant $(H=54.7, p=0.0001)$ under the Tamb treatment (Figure 2).

\section{Locomotor activity}

In the foraging speed trial, higher walking speed was observed in the Tamb + treatment $(2.40 \mathrm{~cm} / \mathrm{s})$ than in Tamb $(1.89 \mathrm{~cm} / \mathrm{s})(W=99, p=0.0003)$ (Figure 5).

The mean speed of the workers gradually increased in function of an increase in the temperature, up to a maximum speed of $2.85 \mathrm{~cm} / \mathrm{s}$ at $22^{\circ} \mathrm{C}$, and then it gradually decreased up to $32^{\circ} \mathrm{C}$ (Figure 6).

\section{Discussion \\ Foraging activity}

The leaf-cutting ant A. lobicornis is considered as a generalist species in regard to its choice of forage plants (Pilati et al. 1997; Claver 2000; Franzel and Farji-Brener 2000). However, if the percentages for each item harvested in our study over the total biomass foraged in both treatments are taken into account, we can define a variable level of preference for each forage item harvested.

The results observed, which show a selective rate of harvesting of certain items, can be explained by two hypotheses. The first is related to chemical defenses present in certain plants that have a variable content of components which are toxic or disagreeable to ants (tanins, alcaloids) (Farji Brener and Protomastro 1992; Franzel and Farji-Brener 2000; Caffarini et al. 2008). This assumes that the presence of components that are disagreeable to ants in a forage item would lead to a lower harvesting rate of this item. The second hypothesis refers to the balance that exists in every plant species between components that are degradable and nondegradable by the symbiotic fungus (Pilati et al. 1997; Gomes de Siqueira et al. 1998; Franzel and Farji-Brener 2000; Abril and Bucher 2004; Bucher and Marchesini 2004). The nutritional interactions between the fungus (Leucoagaricus) and the ants are largely unknown, although it appears that there may be enzymatic contributions from both symbiotic partners in the degradation and processing of the collected plant material (Richard et al. 2005; Erthal et al. 2004). Plant components which symbiotic fungi are not capable of degrading are the following: hemicellulose, cellulose, lignin, and silicon; and the degradable components are the following: soluble 


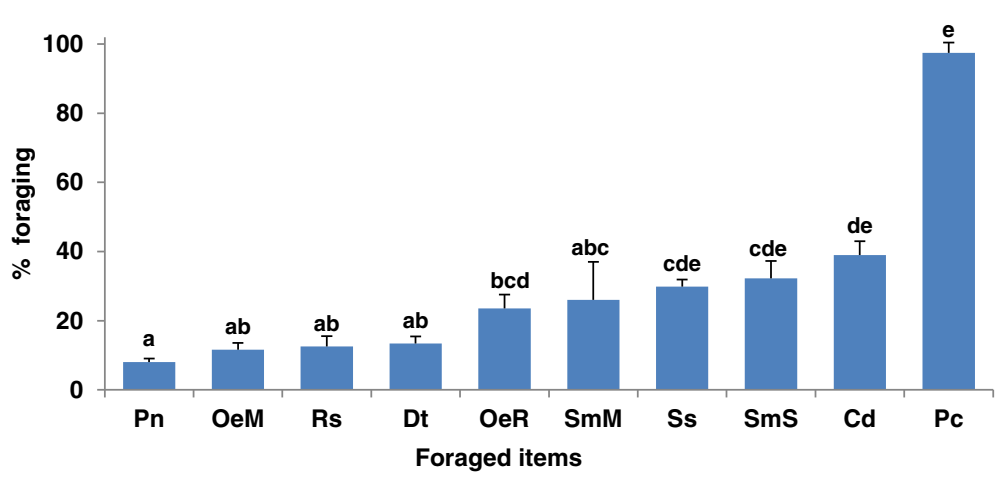

Figure 2 Treatment at ambient temperature. Foraged items: Cd, Cynodon dactylon; Dt, Diplotaxis tenuifolia; OeM, Olea europaea (mature); OeR, Olea europaea (shoot); Pn, Piptochaetium napostaense; Pc, Prunus cerasifera; Rs, Rhynchosia senna; SmM, Schinus molle (mature); SmS, Schinus molle (dry); Ss, Solanum sisymbriifolium. Bars with different letters show significant differences $(p<0.05)$.

carbohydrates (cotton and xylose), phenols, and pectins (according to the enzymatic activity of the fungus) (Gomes de Siqueira et al. 1998; Abril and Bucher 2004; Bucher and Marchesini 2004; De Fine Licht et al. 2009). This hypothesis assumes that the forage items with less compounds that are not degradable by the fungus would have higher harvest rates. The first hypothesis does not explain the case of the $S$. molle item, since the level of preference was intermediate due to its high content of essential oils that have a repellent and toxic effect (Iannacone and Lamas 2003; Werdin González et al. 2008). The second hypothesis seems to explain better the differential preference between different forage items. This hypothesis, for example, confirms that when two forage items Cynodon dactylon and $P$. napostaense are compared, they show high and low levels of preference, respectively. There are different assays for qualifying the forage value of a plant, such as NDF analysis (Neutral Detergent Fiber), which indicates the percentage of insoluble components from plant cell walls present in a solution of neutral detergent (basically cellulose, hemicellulose, lignin, and silicon). The values recorded for these species are up to $76 \%$ for $C$. dactylon and up to $82 \%$ for P. napostaense (Van Soest 1994; Juárez Reyes et al. 2009). Moreover, it should be noted that $C$. dactylon is described as a tropical grass and $P$. napostaense as temperate and, in general, tropical grasses have higher NDF values than those of temperate climates since more metabolic energy is invested in the supporting and conducting tissues than in reserve tissue. These values support the idea that the higher the content of components non-degradable by symbiotic fungi, the lower the level of harvesting preference by the workers. On the other hand, the item with the highest harvesting rate was petals of $P$. cerasifera that has a low content of cellulose, lignin, and hemicellulose which are abundant cell wall components, e.g., in supporting and conducting tissues, and are more developed in stems and leaves (Bidwell 1993). Leaf-cutting ants show foraging preference for young plant tissues, e.g., the apical meristems of young plants, either due to the low content of cellulose and lignin or defense chemicals (Saluso and Xavier 2010), which we could also confirm in our study, as seen in the higher harvesting rate of

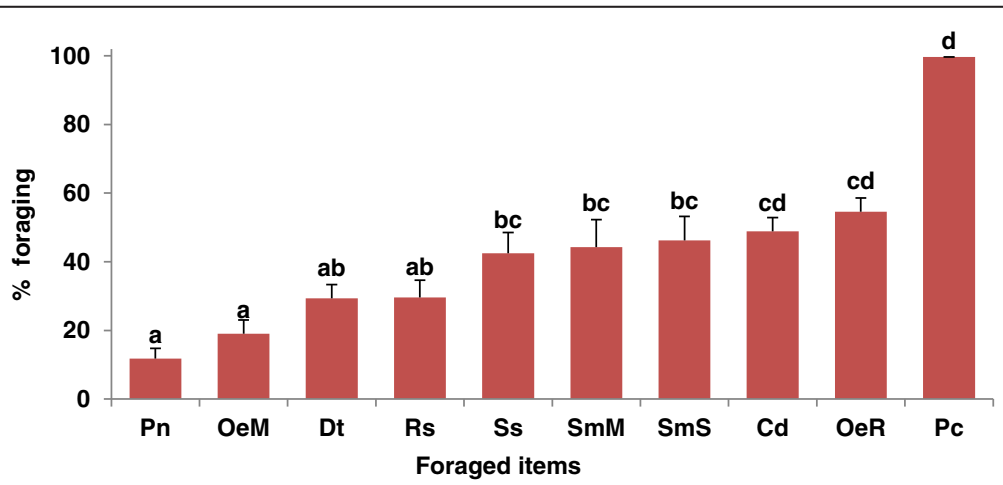

Figure 3 Treatment at ambient temperature $+4.5^{\circ} \mathrm{C}$. Foraged items: Cd, Cynodon dactylon; Dt, Diplotaxis tenuifolia; OeM, Olea europaea (mature); OeR, Olea europaea (shoot); Pn, Piptochaetium napostaense; Pc, Prunus cerasifera; Rs, Rhynchosia senna; SmM, Schinus molle (mature); SmS, Schinus molle (dry); Ss, Solanum sisymbriifolium. Bars with different letters show significant differences $(p<0.05)$. 

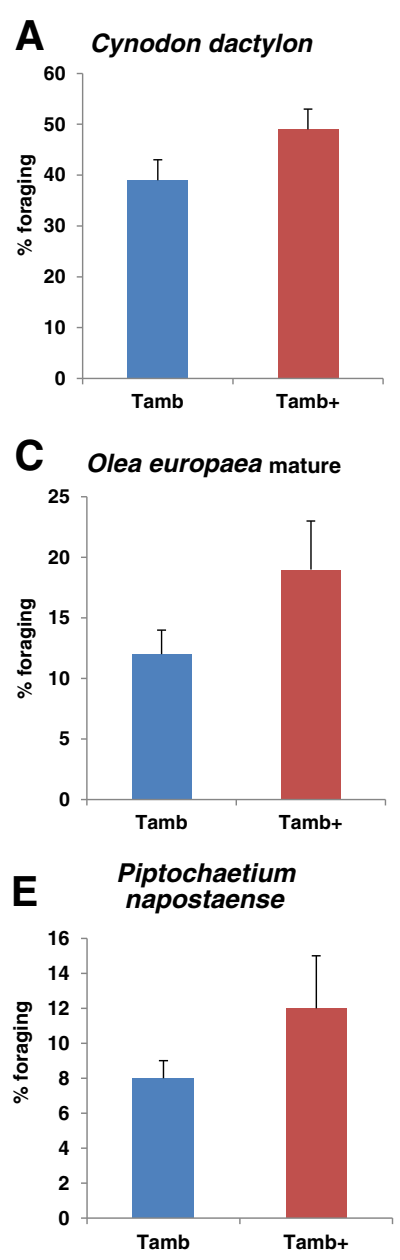

G Rhynchosia senna
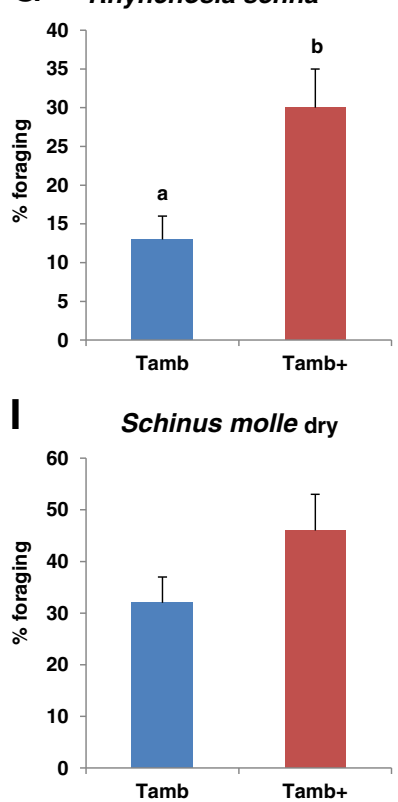

B Diplotaxis tenuifolia

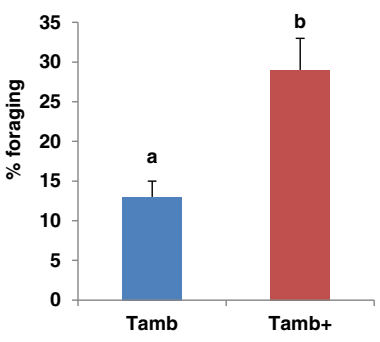

D Olea europaea shoot
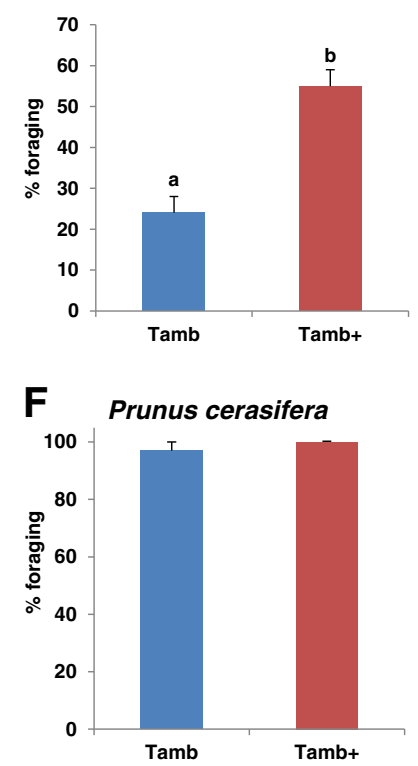

H Schinus molle mature

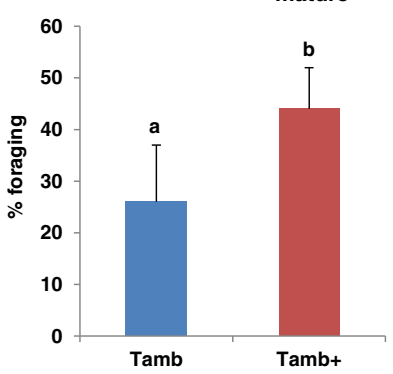

J Solanum sisymbriifolium

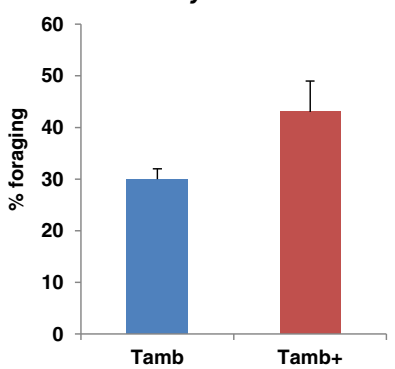

Figure 4 (See legend on next page.) 
(See figure on previous page.)

Figure 4 Harvesting percentages of the ten forage items and differences in foraging rate. Harvesting percentages of the ten forage items and differences in foraging rate (in proportions) under each treatment for each item, with the associated SE in each case. (A) Cynodon dactylon. (B) Diplotaxis tenuifolia. (C) Olea europaea mature. (D) Olea europaea shoot. (E) Piptochaetium napostaense. (F) Prunus cerasifera. (G) Rhynchosia senna. (H) Schinus molle mature. (I) Schinus molle dry. (J) Solanum sisymbriifolium. The bars with different letters indicate significant differences $(p<0.05)$. Harvesting percentages of the ten forage items, and differences in foraging rate (in proportions) under each treatment for each item, with the associated SE in each case. The bars with different letters indicate significant differences $(p<0.05)$.

O. europaea in the form of leaves from a shoot (11\%) in comparison to mature leaves of the same species $(4.3 \%)$. This phenomenon is in agreement with that observed in the quality analysis of forage plants. The content of proteins and insoluble fibers (cellulose, hemicellulose, and lignin) varies in each plant according to its state of maturity (phenological stage). The young plants possess a high content of proteins and low content of insoluble fibers in comparison to mature plants in which the protein content is lower and the content of insoluble fibers associated with conducting and supporting tissues is increased (Van Soest 1994; Juárez Reyes et al. 2009). This high content of proteins in leaves and young organs, compounds that are degradable by the symbiotic fungus, and the low insoluble fiber content that the fungus is not capable of degrading successfully might explain why the workers harvest these types of forage items preferentially.

It should be clarified that all the forage plants had been harvested by ants in the field during the study. Moreover, the length of the trial was too short to assume any positive signal on the part of the fungus as feedback from the workers on what they harvested. In the leafcutting ants in particular, the environmental element that activates a 'positive signal' for harvesting originates in the symbiotic fungus cultivated by the colony and there is a positive correlation between the plant

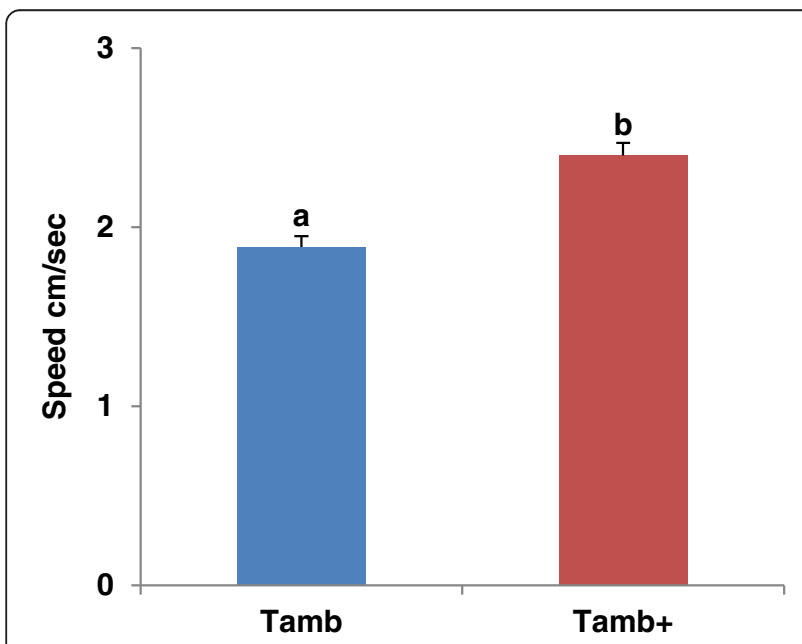

Figure 5 Walking speed of the workers under both treatments

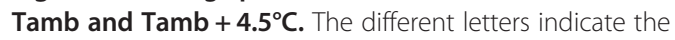
significant differences $(p<0.05)$. materials harvested by the workers and the capacity of the fungus to metabolize it (Saverschek and Roces 2011).

When we analyze the harvesting rate by treatment, we can see that the magnitude of harvest for all forage items was greater under the $+4.5^{\circ} \mathrm{C}(\mathrm{Tamb}+)$ ambient temperature treatment. These observations are in agreement with the harvesting patterns of A. lobicornis and its relationship with temperature observed by Pilati and Quirán (1996). In the Tamb + treatment, with an ambient temperature range of $22.2^{\circ} \mathrm{C}$ to $30.1^{\circ} \mathrm{C}$, it was seen that the harvesting rate of all items together was $1 / 3$ greater than for the ambient temperature range of $19.5^{\circ} \mathrm{C}$ to $22.9^{\circ} \mathrm{C}$. Harvesting patterns have been seen for variable temperature ranges for this species: at an ambient temperature of $11.7^{\circ} \mathrm{C}$ to $22.6^{\circ} \mathrm{C}$ (Pilati and Quirán 1996) and a soil temperature of $10^{\circ} \mathrm{C}$ to $40^{\circ} \mathrm{C}$ (Claver 2000) and $17^{\circ} \mathrm{C}$ to $28^{\circ} \mathrm{C}$ (Nobua Behrmann et al. 2010). A temperature range appears to be a variable that predicts the foraging activity in the best way when the harvesting activity of a species is defined a priori. A. lobicornis is an opportunist leaf-cutter that harvests a large variety of plant species (Pilati and Quirán 1996; Pilati et al. 1997; Claver 2000; Franzel and Farji-Brener 2000) and it does so under specific climatic conditions (Pilati and Quirán 1996; Quirán and Pilati 1998; Claver 2000). Studies that analyze competitive interactions between species of ants that forage at the same site point out that they compete for a temperature range that is optimum for their foraging activity (Cerdá et al. 1998; Lessard et al. 2009). If we define a harvesting temperature range for A. lobicornis of $11.7^{\circ} \mathrm{C}$ to $40^{\circ} \mathrm{C}$, as cited in different places, we can see that the Tamb + treatment lies between the mean temperature of this range $\left(25.9^{\circ} \mathrm{C}\right)$ and the upper limit $\left(40^{\circ} \mathrm{C}\right)$. The results obtained in our study assert that the maximum harvesting rate occurs at the highest temperatures within the optimum temperature range (Pilati and Quirán 1996). The highest foraging rate in the higher temperature treatment can be attributed to an effect of the harvesting activity within the upper portion of the optimum harvesting temperature range cited for the species.

Comparing both treatments (Tamb and Tamb+), in the analysis of the rate of harvesting for each forage item, three situations were observed: (1) P. napostaense and $P$. cerasifera were the least and most harvested items, respectively, and there was no variation in the 


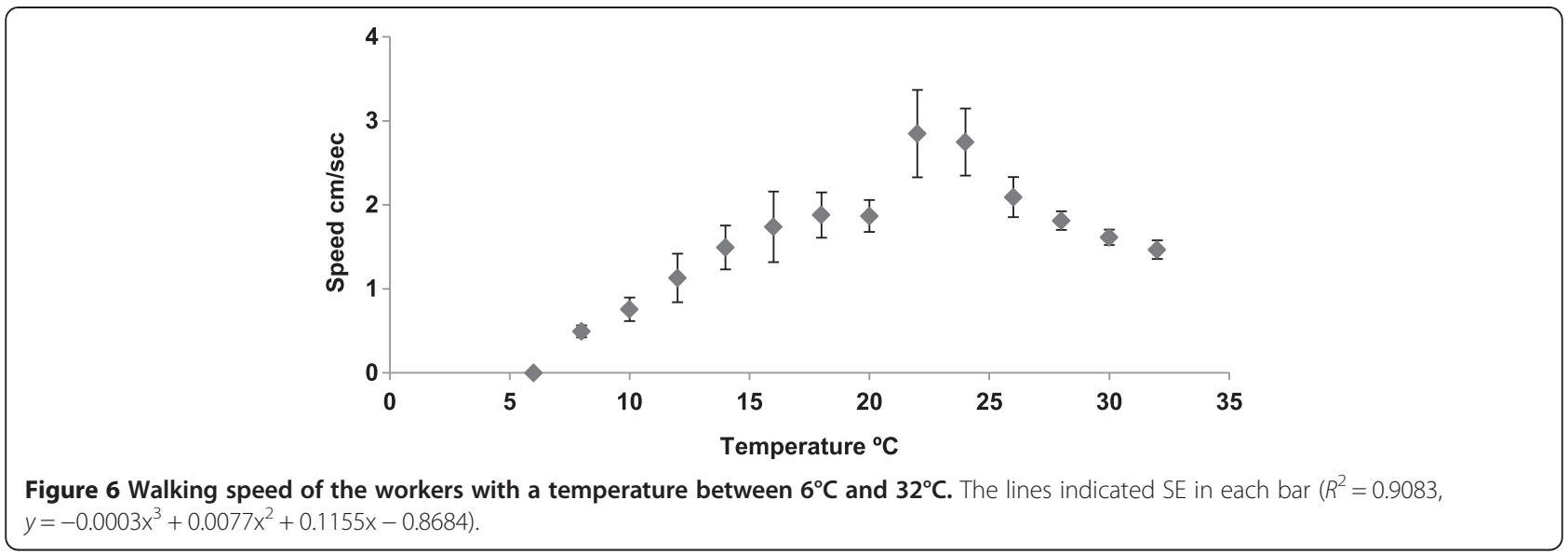

foraging rate due to the difference in temperature; (2) The difference between treatments was not significant for four of the items of intermediate preference; (3) For the remaining four items of intermediate preference, there was a significant difference between treatments. It can be said a priori that the items of intermediate preference are harvested differentially according to the ambient temperature; but for the highest and lowest levels of preference, no link was detected between the harvesting rate and the variation in temperature. However, if we take the percentages of each item harvested into account for both treatments together and we put the percentages of foraging over the total biomass harvested into order, we can see the exceptions: $D$. tenuifolia and $O$. europaea (shoot) that correspond to $5.8 \%$ and $11 \%$ of the total biomass harvested, respectively, showed differences under both treatments. If we define a gradient of foraging preference for the ten forage items, we find that $D$. tenuifolia and O. europaea (shoot) are placed in the lowest and highest preference levels, respectively. On the other hand, if we consider S. molle (mature) and Solanum sisymbriifolium that correspond to $9.7 \%$ and $10.1 \%$ of the total biomass harvested, respectively (a more intermediate level of preference), the differences in harvesting rate between both treatments were not significant. Moreover, if we consider the difference in harvesting rates between treatments for each item (in percentages), the value that separates the three groups or situations previously described is only 2 or 3 units. In conclusion, it would be correct to assert that the differences in the rates of harvesting for each forage item under each treatment, whether significant or not, may be an artifact of the experiment and a chance effect, but it can also be stated that the forage rate is greater when there is an increase in temperature when referring to all the items together, although this difference is not seen for each individual foraged item.
Lastly, when we look in particular at the two plant species that were presented in two different forms, O. europaea (shoot and mature) and S. molle (mature and dry), in both cases, the harvesting differential at different temperatures may be in response to the needs of the colony. O. europaea (shoot) was harvested in greater proportion in both treatments, being only statistically significant under the higher temperature treatment. This might be due to the behavior of the workers, as the colony expands when the temperature is elevated and nutritional needs are prioritized (Pilati et al. 1997). On the other hand, in the case of $S$. molle, in which the dry state was harvested in greater proportion at lower temperatures, it may be that the ants were harvesting chaff for the construction of an anthill to protect the nest during the low winter temperatures, which occurs in autumn when the ambient temperature starts to drop (Pilati et al. 1997; Bollazzi 2008; Perez 2009).

\section{Locomotor activity}

Two trials on the walking speed of the workers were performed in this study. The first was carried out during the trial on foraging activity when the walking speed was measured under two temperatures separated by an average thermic amplitude of $4.5^{\circ} \mathrm{C}$. The second was designed with the measurement of walking speed as the only objective, when the way in which the walking speed changes under a gradient of ambient temperature $\left(6^{\circ} \mathrm{C}\right.$ to $32^{\circ} \mathrm{C}$ ) was evaluated. In the first trial, it was shown that a thermic amplitude of $4.5^{\circ} \mathrm{C}$ is sufficient to increase the walking speed of the workers by more than $20 \%$. The walking speed of the workers of A. lobicornis increases as the ambient temperature increases, up to a given maximum, and then it starts to drop as the ambient temperature continues to rise. This phenomenon has also been seen in other ant species in a similar pattern, although the maximum speed may be reached at 
different temperatures (Angilletta et al. 2008; Bollazzi and Roces 2011). Ants from different species or colonies that forage at the same site compete for resources, as well as for the ambient temperature in which they carry out their foraging activity, the dominant species foraging within the most suitable ranges of temperature for the activity (Cerdá et al. 1998; Lessard et al. 2009). In this way, an equilibrium is established when different groups forage at different times of the day, since each group is active within a determined temperature range and small variations of a few degrees do not alter the foraging activity (Chambers 2011). A. lobicornis forages in a temperature range of $10^{\circ} \mathrm{C}$ to $40^{\circ} \mathrm{C}$ either by day or by night (Pilati and Quirán 1996; Claver 2000; Nobua Behrmann et al. 2010). The results obtained show that for this species that harvests within a range with a $30^{\circ} \mathrm{C}$ amplitude, a difference of $4.5^{\circ} \mathrm{C}$ is a sufficient thermic amplitude to make a significant change in the walking speed of the workers. In the second walking speed trial, with similar sizes of workers, the walking speed was seen to increase up to a maximum between $22^{\circ} \mathrm{C}$ and $24^{\circ} \mathrm{C}$, after which it began to drop down. As has already been said, this pattern of walking speed, which can be associated with foraging activity, is similar for different species, but the maximums are reached at different temperatures. This behavior might be explained by two hypotheses. The first refers to the thermic tolerance range of each species. However, the second hypothesis assumes that the competitive interactions between different groups of ants at the same site define the temperature range within which each species forages and so the walking speed is associated with this activity (Cerdá et al. 1998; Lessard et al. 2009). On the basis of the first hypothesis, we can mention the example of thermic tolerance and the range of activity of two ant species, Atta sexdens and A. lobicornis, which have similar thermic tolerance ranges. However, the former species reaches its maximum walking speed between $6^{\circ} \mathrm{C}$ and $8^{\circ} \mathrm{C}$ higher than the latter species (Pilati and Quirán 1996; Claver 2000; Angilletta et al. 2007, 2008; Nobua Behrmann et al. 2010). The thermic tolerance differential per species does not explain satisfactorily why each group of ants reaches its maximum walking speed at different temperatures. So the second hypothesis appears to give a possible explanation for the differences between the species, but it cannot be put to test without observing the patterns of foraging of the ant species present in the study area and how they relate in respect to the temperature and to each other.

The efficiency with which the workers carry out the foraging activity might be related to the size of item that each worker carries (Quirán and Steibel 2001; Bollazzi and Roces 2011). Although we could also relate it to the walking speed of the workers, as the foraging efficiency of a species not only depends on the size of item carried by the workers but also on the speed at which it is transported to the nest. In this study, we were able to see that as the ambient temperature increased the workers' harvesting for more forage $(1 / 3$ more plant biomass for a difference of $4.5^{\circ} \mathrm{C}$ ), and moreover they moved at a greater speed up to a maximum at a determined temperature $\left(22^{\circ} \mathrm{C}\right.$ to $\left.24^{\circ} \mathrm{C}\right)$ and then began to move more slowly from then onwards. Therefore, it could be said that an increase in the ambient temperature up to around $25^{\circ} \mathrm{C}$ increases the harvesting efficiency of A. lobicornis. Since the temperature in summer is often above this level but it is not reached during the winter, global warming will have the tendency to make a significant impact on the harvesting activity of this species in late autumn and early spring.

The speeds differed according to the experiment (foraging and walking activities); when the temperature was around $22^{\circ} \mathrm{C}$, the speed was higher in the walking experiment and at $26^{\circ} \mathrm{C}$ it was the opposite. This can be explained by the fluctuation in ambient temperature in the foraging experiment, similar to the outside (maximum day temperature and minimum night temperature). This amplitude allows the workers to rest when the temperature is high. On the other hand, in the speed experiment, the workers were in a chamber at a constant temperature each day (day and night).

Ants are ectothermic and they are directly affected by the ambient temperature when outside their nests (Bale et al. 2002; Angilletta et al. 2002; Deutsch et al. 2008). However, they can actively control the microclimate inside their nests by alleviating, isolating, or holding back the heat with their characteristic structures (Quirán and Pilati 1998; Kleineidam et al. 2001; Bollazzi and Roces 2007). So, species of Acromyrmex have developed specific mechanisms to control the microclimate of the nest, creating thermic stability which allows them to live under extreme conditions of humidity and temperature (Quirán and Pilati 1998). The workers can move the fungus gardens to the most appropriate areas in the nest and change the architecture which has an affect on the ventilation $\left(\mathrm{O}_{2}-\mathrm{CO}_{2}\right.$ exchange) (Kleineidam et al. 2001; Bollazzi and Roces 2007) and stir up the soil around the nest which increases its porosity. Moreover, as the soil density is decreased, it favors the infiltration of water and gaseous exchange (Quirán and Pilati 1998; Kleineidam et al. 2001). In both experiments undertaken in this study, the capacity of the ants to move the fungus and to remodel the nest was limited; however, the aim of this study was principally to measure the effects of temperature on activities outside the nests.

\section{Conclusions}

The projections generated for the climatic model by CIMA/CONICET show an increase in temperature of 
between $2^{\circ} \mathrm{C}$ and $4.5^{\circ} \mathrm{C}$ in the next 80 years for the region that extends from the north of Argentina to the north of Patagonia. The geographic distribution of A. lobicornis within Argentina is from the north of the country to the $44^{\circ} \mathrm{S}$ parallel. In our study we observed that an increase of $4.5^{\circ} \mathrm{C}$ in the ambient temperature was sufficient to make an impact on the activity of leaf-cutting ants:

- Higher rate of harvesting (33\% higher)

- Significantly faster walking speed (27\% higher)

If we consider all the facts discussed in this study together (plasticity in the diet of leaf-cutting ants, harvesting a wide variety of plant species - monocotyledons and dicotyledons; a preference for harvesting young leaves with a low percentage of cellulose, hemicellulose, lignin, and waxes; highly capable of becoming adapted to different sites and climates; behavioral habits that allow it to become adapted to a variation in ambient temperature; and a citation of the species in the $\mathrm{N}$ of Patagonia where the ambient temperature is a limiting factor for the species), in the face of a global warming scenario, with an increase in temperature of between $2^{\circ} \mathrm{C}$ and $4.5^{\circ} \mathrm{C}$ for this area, it can be seen that this species might become a pest of greater magnitude (Perez 2009, although currently described as a moderate pest by Fowler et al. 1986), foraging not only on crops and forest plantations but also with increased foraging pressure on native plant species. It could also become more competitively aggressive to other animal species that forage in the same area as A. lobicornis.

\section{Competing interests}

The authors declare that they have no competing interests.

\section{Authors' contributions}

RT wrote the preliminary draft of this manuscript, carried out the design and coordination of the study. RT and JPW carried out the experiment. DVP gave advice in the statistical analysis and revised the manuscript. All authors have read and approved the final version of the manuscript.

\section{Acknowledgements}

We are thankful to Omar Elia and Osvaldo Fernández for the materials (glass tanks) for the experiments. We are grateful to Aaron Ellison PhD for first project ideas. We thank the reviewers for substantially improving the manuscript. This study was supported by the CERZOS CCT-Bahía Blanca CONICET.

\section{Author details}

'CERZOS-CONICET, CCT-Bahía Blanca, San Andrés 850, Bahía Blanca 8000, Argentina. ${ }^{2}$ Departamento de Biología, Bioq. Y Farm, UNS; CERZOS-CONICET, CCT-Bahía Blanca, San Andrés 850, Bahía Blanca 8000, Argentina. ${ }^{3} \mathrm{CIC}$; CERZOS-CONICET, CCT-Bahía Blanca, San Andrés 850, Bahía Blanca 8000, Argentina.

Received: 13 August 2013 Accepted: 4 July 2014

Published: 1 August 2014

\section{References}

Abril AB, Bucher EH (2004) Nutritional sources of the fungus cultured by leafcutting ants. Appl Soil Ecol 26:243-247
Aeródromo de Bahía Blanca (2011) Clima en Bahia Blanca Aerodrome [on line]. http://www.tutiempo.net/clima/Bahia_Blanca_Aerodrome/877500.htm Accessed September 2011

Angilletta MJ, Niewiarowski PH, Navas CA (2002) The evolution of thermal physiology in ectotherms. J Therm Biol 27:249-268

Angilletta MJ, Wilson RS, Niehaus AC, Sears MW, Navas CA, Ribeiro PL (2007) Urban physiology: city ants possess high heat tolerance. PLoS ONE 2:e258

Angilletta MJ, Roth TC, Wilson RS, Niehaus AC, Ribeiro PL (2008) The fast and the fractalous: speed and tortuosity trade off in running ants. Funct Ecol 22:78-83

Bale JS, Masters GJ, Hodkinson ID, Awmack C, Bezemer TM, Brown VK, Butterfield JEL, Buse A, Coulson JC, Farrar J, Good JEG, Harrington R, Hartley S, Jones TH, Lindroth RL, Press MC, Symrnioudis I, Watt AD, Whittaker JB (2002) Herbivory in global climate change research: direct effects of rising temperatures on insect herbivores. Glob Change Biol 8:1-16

Balzarini M, Gonzalez L, Tablada M, Casanoves F, Di Rienzo JA, Robledo CW (2008) Infostat. Manual del Usuario, Editorial Brujas, Córdoba, Argentina

Bestelmeyer BT (2000) The trade-off between thermal tolerance and behavioural dominance in a subtropical South American ant community. J Anim Ecol 69:998-1009

Bidwell RGS (1993) Fisiología Vegetal. 1era edición en español. AGT EDTTOR S.A.México

Bollazzi M (2008) Building behaviour and the control of nest climate in Acromyrmex leaf-cutting ants. Doctoral thesis - Deutscher Akademischer Austauschdienst, Germany

Bollazzi M, Roces F (2007) To build or not to build: circulating dry air organizes collective building for climate control in the leaf-cutting ant Acromyrmex ambiguus. Anim Behav 74(5):1349-1355

Bollazzi M, Roces F (2010) Control of nest water losses through building behavior in leaf-cutting ants (Acromyrmex heyeri). Insect Soc 57:267-273

Bollazzi M, Roces F (2011) Information needs at the beginning of foraging: grass-cutting ants trade off load size for a faster return to the nest. PLoS ONE 6(3):e17667

Bollazzi M, Kronenbitter J, Roces F (2008) Soil temperature, digging behaviour and the adaptive value of nest depth in South American species of Acromyrmex leaf-cutting ants. Oecologia 158:165-175

Bucher EH, Marchesini V (2004) Herbivory by leaf-cutting ants: nutrient balance between harvested and refuse material. Biotropica 36(3):327-332

Buckley LB, Jetz W (2008) Linking global turnover of species and environments. PNAS 105:17836-17841

Bucy AM, Breed MD (2006) Thermoregulatory trade-offs result from vegetation removal by a harvester ant. Ecol Entomol 31(5):423-429

Caffarini P, Carrizo P, Pelicano A, Roggero P, Pacheco J (2008) Efectos de extractos acetónicos y acuosos de Ricinus communis (ricino), Melia azedarach (paraíso) y Trichillia glauca (trichillia), sobre la hormiga negra común (Acromyrmex lundi) effects of acetonic and water extracts of Ricinus communis, Melia azedarach y Trichillia glauca on black common cutting ant (Acromyrmex lundi). Idesia 26(1):59-64

Cerdá X, Retana J, Cros S (1998) Critical thermal limits in Mediterranean ant species: trade-off between mortality risk and foraging performance. Funct Ecol 12(1):45-55

Chambers CM (2011) The effects of resource availability and temperature on ants. University of Tennessee Honors Thesis Projects, Knoxville, http://trace. tennessee.edu/utk_chanhonoproj/1447 Accessed September 2011

Claver S (2000) Ecología de Acromyrmex lobicornis (E.) (Hymenoptera: Formicidae) en la Reserva de Biosfera de Ñacuñán, provincia Biogeográfica del Monte. Tesis de Doctorado - Facultad de Ciencias Naturales y Museo. Universidad Nacional de La Plata, Buenos Aires

Cole BJ, Smith AA, Huber ZJ, Wiernasz DC (2010) The structure of foraging activity in colonies of the harvester ant, Pogonomyrmex occidentalis. Behav Ecol 21(2):337-342

Cooper BS, Williams BH, Angilletta MJ (2008) Unifying indices of heat tolerance in ectotherms. J Therm Biol 33:320-323

De Fine Licht HH, Schiøtt M, Mueller UG, Boomsma JJ (2009) Evolutionary transitions in enzyme activity of ant fungus gardens. Evolution 64(7):2055-2069

Deutsch C, Tewksbury JJ, Huey RB, Sheldon K, Ghalambor C, Haak D, Martin PR (2008) Impacts of climate warming on terrestrial ectotherms across latitude. PNAS 105(16):6668-6672

Dimarco RD, Farji-Brener AG, Premoli AC (2010) Dear enemy phenomenon in the leaf-cutting ant Acromyrmex lobicornis: behavioral and genetic evidence. Behav Ecol 21:304-310 
Erthal M Jr, Silva CP, Samuels RI (2004) Digestive enzymes of leaf-cutting ants, Acromyrmex subterraneus (Hymenoptera: Formicidae: Attini): distribution in the gut of adult workers and partial characterization. J Insect Physiol 50:881-891

Farji Brener AG, Protomastro JJ (1992) Patrones forrajeros de dos especies simpátricas de hormigas cortadoras de hojas (Attini, Acromyrmex) en un bosque subtropical seco. Ecotrópicos 5:32-43

Farji-Brener AG, Ruggiero A (1994) Leaf-cutting ants (Atta and Acromyrmex) inhabiting Argentina: patterns in species richness and geographical ranges sizes. J Biogeogr 21:535-543

Fisher JB (1954) Evolution and Bird Sociality. In: Huxley J, Hardy AC, Ford EB (eds) Evolution as a Process. Allen, Unwin, London, pp 71-83

Fowler GH, Pereira-da-Silva V, Forti LC, Saes NB (1986) Population dynamics of leaf-cutting ants. A brief review. In: Lofgren CS, Vander Meer RK (eds) Fire ants and leaf cutting ants: biology and management. Westview, Boulder, pp 123-145

Franzel C, Farji-Brener AG (2000) ¿Oportunistas o selectivas? Plasticidad en la dieta de la hormiga cortadora de hojas Acromyrmex lobicornis en el $\mathrm{N}-\mathrm{O}$ de la Patagonia. Ecología Austral 10:159-168

Gomes de Siqueira C, Bacci M, Pagnocca FC, Correa Bueno O, Aparecida Hebling MJ (1998) Metabolism of plant polysaccharides by Leucoagaricus gongylophorus, the symbiotic fungus of the leaf-cutting ant Atta sexdens L. Appl Environ Microbiol 64(12):4820-4822

Hartley S, Lester PJ (2003) Temperature-dependent development of the argentine ant, Linepithema humile (Mayr) (Hymenoptera: Formicidae) a degree-day model with implications for range limits in New Zealand. New Zealand Entomologist 26:91-100

Hochochka PW, Somero GN (2002) Biochemical adaptation. Oxford University Press, Oxford

Hölldobler B, Lumsden CJ (1980) Territorial strategies in ants. Science 210:732-739

Hölldobler B, Wilson E (1990) The ants. Harvard University Press, Cambridge

Huey RB, Stevenson RD (1979) Integrating thermal physiology and ecology of ectotherms: discussion of approaches. Am Zool 19:357-366

lannacone J, Lamas G (2003) Efecto toxicológicos de extractos de molle (Schinus molle) y lantana (Lantana camara) sobre Chrysoperla externa (Neuroptera: Chrysopidae), Trichogramma pintoi (Hymenoptera: Trichogrammatidae) y Copidosoma koehleri (Hymenoptera: Encyrtidae) en el Perú. Agri Téc (Chile) 63:347-360

IPCC (2007) Cambio climático 2007: Informe de síntesis. Contribución de los Grupos de trabajo I, II y III al Cuarto Informe de evaluación del Grupo Intergubernamental de Expertos sobre el Cambio Climático [Pachauri, R.K. y Reisinger, A. (directores de la publicación)]. IPCC, Ginebra, Suiza

IPCC et al (2001) In: Houghton JT (ed) Climate change 2001: the scientific basis. Cambridge University Press, New York

Juárez Reyes AS, Cerrillo Sotoa MA, Gutiérrez Ornelasb E, Romero Treviñoc EM, Colín Negreteb J, Bernal Barragán H (2009) Estimación del valor nutricional de pastos tropicales a partir de análisis convencionales y de la producción de gas in vitro. Téc Pecu Méx 47(1):55-67

Jumbam KR, Jackson S, Terblanche JS, McGeoch MA, Chown SL (2008) Acclimation effects on critical and lethal thermal limits of workers of the Argentine ant, Linepithema humile. J Insect Physiol 54:1008-1014

Kaspari M (2004) Using the metabolic theory of ecology to predict global patterns of abundance. Ecology 85:1800-1802

Kaspari M, O'Donnell S, Kercher JR (2000a) Energy, density, and constraints to species richness: studies of ant assemblages along a productivity gradient. Am Nat 155:280-293

Kaspari M, O'Donnell S, Alonso L (2000b) Three energy variables predict ant abundance at a geographic scale. Proc R Soc B 267:485-490

Kaspari M, Ward P, Yuan M (2004) Energy gradients and the geographic distribution of local ant diversity. Oecologia 140:407-414

Kleineidam C, Ernst R, Roces F (2001) Wind-induced ventilation of the giant nests of the leaf-cutting ant Atta vollenweideri. Naturwissenschaften 88(7):301-305

Kusnezov N (1978) Hormigas Argentinas: Clave para su identificación. Edición preparada por R. Golbach. Miscelánea 61, Fundación Miguel Lillo

Lambardi D, Dani FR, Turillazzi S, Boomsma JJ (2007) Chemical mimicry in an incipient leaf-cutting ant social parasite. Behav Ecol Sociobiol 61:843-851

Lessard JP, Dunn RR, Sanders NJ (2009) Temperature-mediated coexistence in temperate forest ant communities. Insect Soc 56:149-156

May ML (1979) Insect thermoregulation. Ann Rev Entomol 24:313-349

Mueller UG, Mikheyev AS, Honga E, Sena R, Warrena DL, Solomon SE, Ishaka HD, Cooper M, Millera UL, Shaffera KA, Juenger TE (2011) Evolution of cold-tolerant fungal symbionts permits winter fungiculture by leafcutter ants at the northern frontier of a tropical ant-fungus symbiosis. PNAS 108:4053-4056

Nobua Behrmann BE, Milesi FA, de Casenave Lopez J, Farji-Brener A (2010) Patrones diarios y estacionales de actividad de dos especies simpátricas de hormigas cortadoras de hojas en el desierto del Monte central. IV Reunión Binacional de Ecología (XXIV Reunión Argentina de Ecología y XVII Reunión de la Sociedad de Ecología de Chile), Buenos Aires, Argentina

Nuñez MN (2009) Cambio climático y el clima esperado para Argentina. Mundo Agro 2007. Tecnología y Sustentabilidad. 17-22. SEMA, Buenos Aires

Nuñez MN, Solman S, Cabré MF, Rolla A (2005) Estimación de escenarios regionales de cambio climático mediante el uso de modelos climáticos regionales. Informe Final CIMA/CONICET B-9 Modelos Climáticos Regionales. GEF BIRF PF 51286 AR,

Perez SP (2009) Riesgo potencial de la hormiga cortadora de hojas Acromyrmex lobicornis para las plantaciones forestales de la Patagonia. In: Villacide J, Corley J (eds) Manejo Integrado de Plagas Forestales. Laboratorio de Ecología de Insectos EEA, INTA, Bariloche, Cuadernillo Nº 6

Pilati A, Quirán E (1996) Patrones de cosecha de Acromyrmex lobicornis (Formicidae: Attini) en un pastizal del Parque Nacional Lihué Calel, La Pampa, Argentina. Ecología Austral 7:123-126

Pilati A, Quirán EM, Estelrich HD (1997) Actividad forrajera de Acromyrmex lobicornis Emery (Hymenoptera: Formicidae) en un pastizal natural semiárido de la provincia de La Pampa (Argentina). Ecología Austral 7:49-56

Pol R, Lopez de Casenave J (2004) Activity patterns of harvester ants Pogonomyrmex pronotalis and Pogonomyrmex rastratus in the central Monte desert, Argentina. J Insect Behav 17(5):647-661

Poulsen M, Boomsma JJ (2005) Mutualistic fungi control crop diversity in fungus-growing ants. Science 307:741-744

Quirán EM, Pilati A (1998) Estructura de los hormigueros de Acromyrmex lobicornis (Hymenoptera: Formicidae) en un sitio natural semiárido de La Pampa, Argentina. Rev Soc Entomol Argent 57(1-4):45-48

Quirán EM, Steibel JP (2001) Acromyrmex lobicornis Emery 1887 (Hymenoptera: Formicidae) y el peso de la carga, en condiciones de laboratorio. Gayana (Concepc) 65(2):113-118

Richard FJ, Mora P, Errard C, Rouland C (2005) Digestive capacities of leaf-cutting ants and the contribution of their fungal cultivar to the degradation of plant material. J Comp Physiol B 175:297-303

Richard FJ, Poulsen M, Hefetz A, Errard C, Nash DR, Boomsma JJ (2007) The origin of chemical profiles of fungal symbionts and their significance for nestmate recognition in Acromyrmex leaf-cut- ting ants. Behav Ecol Sociobiol 61:1637-1649

Saluso A, Xavier L (2010) Caracterización del daño producido por la "hormiga negra común" en plántulas de girasol. INTA - EEA Paraná Actualización Técnica № 2 - Maíz, Girasol y Sorgo, pp 101-103

Sanders NJ, Lessard JP, Fitzpatrick MC, Dunn RR (2007) Temperature, but not productivity or geometry, predicts elevational diversity gradients in ants across spatial grains. Global Ecol Biogeog 16:640-649

Saverschek N, Roces F (2011) Foraging leafcutter ants: olfactory memory underlies delayed avoidance of plants unsuitable for the symbiotic fungus. Anim Behav 82:453-458

Storch D (2010) Thermal and energetic controls on biodiversity. In: Gordon Research Conference on Metabolic Basis Of Ecology. University of New England in Biddeford,

Valderrama El, Giraldo C, Montoya-Lerma J, Ambrecht I, Calle Z (2006) Guía para el establecimiento y manejo de colonias artificiales de hormiga arriera Atta cephalotes (Hymenoptera: Myrmicinae). Boletín del Museo de Entomología de la Universidad del Valle 7(2):9-16

Van Soest PJ (1994) Nutritional ecology of the ruminant, 2nd edn. Cornell University Press, Ithaca

Vogt JT, Smith WA, Grantham RA, Wright RE (2003) Effects of temperature and season on Solenopsis invicta Buren (Hymenoptera: Formicidae) foraging in Oklahoma. Environ Entomol 32(3):447-451

Werdin González JO, Murray AP, Ferrero AA (2008) Bioactividad de aceites esenciales de Schinus molle var. areira (Anacardiaceae) en ninfas II de Nezara viridula (Hemiptera: Pentatomidae). Bol San Veg (Plagas) 34:367-375

\section{doi:10.1186/s40555-014-0040-4}

Cite this article as: Tizón et al:: The effect of increase in the temperature on the foraging of Acromyrmex lobicornis (Hymenoptera: Formicidae). Zoological Studies 2014 53:40. 